\title{
Crassiperidium (Pleosporales, Dothideomycetes), a new ascomycetous genus parasitic on Fagus crenata in Japan
}

\author{
Matsumura $\mathbf{M}^{1,2}$, Kato $\mathrm{W}^{1}$, Hashimoto $\mathrm{A}^{3}$, Takahashi $\mathrm{YS}^{4}$, Shirouzu $\mathrm{T}^{5}$ and \\ Tanaka $K^{1,2}$
}

\author{
${ }^{1}$ Faculty of Agriculture and Life Science, Hirosaki University, 3 Bunkyo-cho, Hirosaki, Aomori 036-8561, Japan \\ ${ }^{2}$ The United Graduate School of Agricultural Sciences, Iwate University, 18-8 Ueda 3 chome, Morioka, Iwate 020- \\ 8550, Japan \\ ${ }^{3}$ Faculty of Agriculture and Life Science, Hirosaki University, Aomori, Japan. Present address: Japan Collection of \\ Microorganisms, RIKEN BioResource Research Center, 3-1-1 Koyadai, Tsukuba, Ibaraki, 305-0074, Japan \\ 4 Department of Mushroom Science and Forest Microbiology, Forestry and Forest Products Research Institute, 1 \\ Matsunosato, Tsukuba, Ibaraki 305-8687, Japan \\ 5 Graduate School of Bioresources, Mie University, 1577 Kurima-machiya, Tsu, Mie 514-8507, Japan
}

Matsumura M, Kato W, Hashimoto A, Takahashi YS, Shirouzu T, Tanaka K 2018 Crassiperidium (Pleosporales, Dothideomycetes), a new ascomycetous genus parasitic on Fagus crenata in Japan. Mycosphere 9(6), 1256-1267, Doi 10.5943/mycosphere/9/6/13

\begin{abstract}
A new genus, Crassiperidium, is established to accommodate two new species, $C$. octosporum and C. quadrisporum, found on twigs of the Fagus crenata in Japan. Crassiperidium is characterized by globose to depressed globose ascomata with a well-developed ascomatal wall at the sides, clavate asci, broadly fusiform, hyaline ascospores, pycnidial conidiomata, and cylindrical, multi-septate, hyaline conidia produced by annellidic conidiogenous cells. Phylogenetic analyses of a combined dataset of SSU and LSU nrDNA, and RPB2 revealed that Crassiperidium is close to Cyclothyriellaceae (Pleosporales, Dothideomycetes), but its familial placement was unresolved. The two new species of Crassiperidium have similar-sized ascospores and conidia, but the asci are 8-spored in C. octosporum and 4-spored in C. quadrisporum. Phylogenetic analyses of Crassiperidium species based on the sequences of ITS, TEF1, RPB2, and a combined dataset of these three loci support the validity of these two species.
\end{abstract}

Key words - 3 new taxa - Ascomycota - Cyclothyriellaceae - Phylogeny - Pseudoasteromassaria - Taxonomy

\section{Introduction}

During the ongoing studies on ascomycetous fungi growing on Fagus spp. in Japan (e.g., Hashimoto et al. 2016, 2017a), two undescribed species belonging to the Pleosporales were collected. The morphological characteristics of these species, such as globose to depressed globose ascomata with well-developed ascomatal wall at the sides, clavate asci, broadly fusiform ascospores, pycnidial conidiomata, and cylindrical, multi-septate, hyaline conidia are similar to those of Pseudoasteromassaria. The monotypic genus Pseudoasteromassaria (type species: $P$. fagi) found from the twigs of Fagus crenata in Japan, was recently described and was placed in Latoruaceae following a phylogenetic analysis using sequences of the small and large subunit 
nrDNA (SSU and LSU) (Ariyawansa et al. 2015). On the other hand, preliminary BLAST analysis using the LSU sequences of these fungi suggests that they have phylogenetic affinities with Cyclothyriella and Massariosphaeria belonging to Cyclothyriellaceae (Jaklitsch \& Voglmayr 2016).

Pleosporales is the largest order in the Dothideomycetes, and the taxonomic and phylogenetic relationships of each family/genus within this order are well established (e.g., Zhang et al. 2012, Hyde et al. 2013, Tanaka et al. 2015, Liu et al. 2017, Jaklitsch et al. 2018). Owing to their importance in forest ecosystems, ecologically diverse fungi occurring on Fagus spp., such as F. crenata, F. grandifolia, and F. sylvatica are listed and well-documented (Baird et al. 2007, Unterseher \& Schnittler 2010, Hosoya et al. 2018), but our newly collected fungi on F. crenata do not match any of the previously known genera in Pleosporales. Therefore, we establish a new genus, Crassiperidium, to accommodate two new species, C. octosporum and C. quadrisporum.

\section{Materials \& Methods}

\section{Isolates and morphology}

Microscopic observations and single spore isolations were performed as described by Tanaka et al. (2015). The position of the primary septum of spores was noted using the decimal system (Shoemaker 1984). Specimens are deposited in the Herbarium of Hirosaki University Fungi (HHUF). Single ascospore/conidium cultures were deposited at the Japan Collection of Microorganisms (JCM) and the GenBank Project, NARO (MAFF). Colony characteristics were recorded from growth on potato dextrose agar (PDA) after 2 weeks at $20^{\circ} \mathrm{C}$ in the dark and colony colors were noted according to Rayner (1970). To observe the asexual morph in culture, sporulation was promoted by placing a small piece of mycelial culture on rice straw agar (Tanaka \& Harada 2003).

\section{DNA extraction and phylogenetic analyses}

DNA was extracted from 12 isolates in total using the ISOPLANT II kit (Nippon Gene, Tokyo, Japan) following the manufacturer's instruction. The sequence of SSU, the internal transcribed spacer region of ribosomal DNA (ITS), LSU, translation elongation factor 1-alpha (TEF1), and RNA polymerase second largest subunit (RPB2) was amplified by PCR using primer sets NS1/NS4, ITS1/ITS4 (White et al. 1990), LR0R/LR7 (Rehner \& Samuels 1994), EF-983F/EF2218R (Rehner \& Buckley 2005), and fRPB2-5F/fRPB2-7cR (Liu et al. 1999), respectively. PCR was carried out in $25 \mu \mathrm{L}$ including $2.5 \mu \mathrm{L}$ of $10 \times$ TEMPase Buffer I, $1 \mu \mathrm{L}$ of each $20 \mathrm{pM}$ primer, $25 \mathrm{mM} \mathrm{MgCl}_{2}, 2.5 \mu \mathrm{L}$ of dNTP mix, $14.5 \mu \mathrm{L}$ of ultra pure water and $0.5 \mu \mathrm{L}$ of TEMPase Hot Start DNA Polymerase (Ampliqon, Denmark). Amplifications of each region were performed on a PC 320 thermo-cycler (ASTEC, Japan) as follows: $95^{\circ} \mathrm{C}$ for $15 \mathrm{~min} ; 35$ cycles of $1 \mathrm{~min}$ at $94^{\circ} \mathrm{C}, 1 \mathrm{~min}$ at annealing temperature $\left(42.2^{\circ} \mathrm{C}\right.$ for SSU, $61.5^{\circ} \mathrm{C}$ for ITS, $46^{\circ} \mathrm{C}$ for $\mathrm{LSU}, 60^{\circ} \mathrm{C}$ for $\mathrm{TEF} 1,55^{\circ} \mathrm{C}$ for RPB2), $1 \mathrm{~min}$ at $72^{\circ} \mathrm{C} ; 72^{\circ} \mathrm{C}$ for $7 \mathrm{~min}$. PCR products were sequenced at SolGent (South Korea).

Newly generated sequences were deposited in GenBank (Table 1). Primary analyses of SSU-LSURPB2 sequences from 35 taxa of Pleosporales were analyzed to clarify the familial/generic placement of the fungus (Table 1, Appendix 1). Lophiostoma macrostomum and L. arundinis (Lophiostomataceae) were used as outgroups for the primary analyses. Secondary analyses were conducted on single gene phylogenetic analyses for ITS, TEF1, and RPB2, and the combination of these three from 12 taxa of our newly obtained strains to assess the species boundary. Sequences were aligned using an algorithm implemented in MEGA v. 5.2.2 (Tamura et al. 2011). Phylogenetic analyses were conducted using maximum-likelihood (ML) and Bayesian methods. The optimum substitution models for each data set were estimated using Kakusan4 software (Tanabe 2011) based on the Akaike information criterion (AIC; Akaike 1974) for ML analysis and on Bayesian information criterion (BIC; Schwarz 1978) for the Bayesian analysis. ML analysis was performed using the RAxML-HPC2 v. 8.2.10 on the CIPRES Science Gateway (Miller et al. 2015, Stamatakis 2014) based on models selected with the AICc4 parameter (a separate codon separate 
model for primary analyses and the equalrate codon equalrate model for secondary analyses). The GTR+G model was optimal for all partitions in the primary and secondary dataset. Bootstrap proportions (BPs) were obtained using 1,000 bootstrap replications. Bayesian analysis was performed with MrBayes v. 3.2.6 on the CIPRES Science Gateway (Miller et al. 2015, Ronquist et al. 2012), using substitution models containing the BIC4 parameter (i.e., proportional codon proportional model for each analyses). K80+G was used for SSU, SYM+G for LSU, and GTR+G for RPB2 in the first dataset. The second dataset used $\mathrm{K} 80+\mathrm{G}$ for ITS, F81+H for the first and second position of RPB2, HKY $85+\mathrm{H}$ for the third codon position, F81+H for the TEF1 first codon position, JC69 for the second position, and HKY85+H for the third position. Two simultaneous and independent Metropolis-coupled Markov chain Monte Carlo (MCMC) runs were performed for 2 $\mathrm{M}$ generations with the tree sampled for every 1,000 generations of the analyses. Convergence of the MCMC procedure was assessed from the average standard deviation of split frequencies ( $<$ 0.01) and the effective sample size scores (all > 100) using MrBayes and Tracer v. 1.6 (Rambaut et al. 2014), respectively. The first $25 \%$ of the trees were discarded as burn-in, and the remainder were used to calculate the 50\% majority-rule trees and to determine the posterior probabilities (PPs) for individual branches. These alignments were submitted to TreeBASE under study number S23305.

Table 1 Culture and GenBank accession number of Crassiperidium spp. used in this study.

\begin{tabular}{|c|c|c|c|c|c|c|}
\hline \multirow{2}{*}{ Taxon } & \multirow{2}{*}{ Stain no. } & \multicolumn{5}{|c|}{ GenBank accession no. } \\
\hline & & $\overline{\text { SSU }}$ & ITS & LSU & TEF1 & RPB2 \\
\hline C. octosporum & $\begin{array}{l}\text { KT } 2144=\text { JCM } 17827= \\
\text { MAFF } 242971\end{array}$ & LC373084 & LC373096 & LC373108 & LC373120 & LC373132 \\
\hline C. octosporum & KT 2894 = MAFF 246399 & LC373085 & LC373097 & LC373109 & LC373121 & LC373133 \\
\hline C. octosporum & KT $3008=$ MAFF 246400 & LC373086 & LC373098 & LC373110 & LC373122 & LC3 \\
\hline C. octosporum & KT 3029 = MAFF 246401 & LC373087 & LC373099 & LC373111 & LC373123 & LC373135 \\
\hline C. octosporum & KT $3046=$ MAFF 246402 & LC373088 & LC373100 & LC373112 & LC373124 & LC373136 \\
\hline C. octosporum & KT $3188=$ MAFF 246403 & LC373089 & LC373101 & LC373113 & LC373125 & LC373137 \\
\hline C. octosporum & KT $3468=$ MAFF 246404 & LC373090 & LC373102 & LC373114 & LC373126 & LC373138 \\
\hline C. octosporum & KT $3604=$ MAFF 246405 & LC373091 & LC373103 & LC373115 & LC373127 & LC373139 \\
\hline C. octosporum & KT $3605=$ MAFF 246406 & LC373092 & LC373104 & LC373116 & LC373128 & LC373140 \\
\hline C. octosporum & MM 9 = MAFF 246407 & LC373093 & LC373105 & LC373117 & LC373129 & LC373141 \\
\hline C. quadrisporum & $\begin{array}{l}\text { KT 2798-1 = JCM } 32442= \\
\text { MAFF } 246397\end{array}$ & LC373094 & LC373106 & LC373118 & LC373130 & LC373142 \\
\hline C. quadrisporum & $\begin{array}{l}\text { KT 2798-2 = MAFF } \\
246398\end{array}$ & LC373095 & LC373107 & LC373119 & LC373131 & LC373143 \\
\hline
\end{tabular}

\section{Results}

\section{Phylogenetic analyses}

For the first analysis, ML and Bayesian phylogenetic analyses were conducted using an aligned sequence dataset comprising 983 nucleotide positions from SSU, 1,284 from LSU, and 993 from RPB2. Of the 3,260 characters included in the alignment, 998 were variable and 2,262 were conserved. This combined dataset provided higher confidence values for the familial and generic levels than those of individual gene trees (data not shown). The ML tree with the highest log likelihood (-21060.538) is shown in Fig. 1. The Bayesian likelihood score was -20408.695 . The topology recovered by the Bayesian analysis was identical to that of the ML tree. Crassiperidium spp. formed a sister clade to Cyclothyriella and Massariosphaeria in Cyclothyriellaceae (Fig. 1), but this relationship was not well-supported (Fig. 1).

Alignment of the second analysis was based on 515 nucleotide positions from ITS, 1,032 from RPB2, and 942 from TEF1. Of the 2,489 characters included in the alignment, 92 were variable and 2,397 were conserved. Three individual and combined phylogenies showed almost 
identical tree topologies with branches supported by $>90 \%$ ML BP and $>0.95$ Bayesian PP and indicated two distinct operational taxonomic units (Fig. 2). The ML tree with the highest log likelihood (-858.532 in ITS, -1554.488 in RPB2, -1407.289 in TEF1, and -3886.896 in ITSRPB2-TEF1) is shown in Fig. 2. The Bayesian likelihood score was -877.519 in ITS, -1559.689 in RPB2, -1411.493 in TEF1, and -3871.473 in ITS-RPB2-TEF1. All the topology recovered by Bayesian analysis was identical to that of the ML tree. Two monophyletic clades of Crassiperidium (C. octosporum and C. quadrisporum) were fully supported by both ML and Bayesian analyses in all datasets (Fig. 2).

\section{Taxonomy}

Crassiperidium M. Matsum. \& Kaz. Tanaka, gen. nov. Index Fungorum number: IF555726; Facesoffungi number: FoF05595

Etymology - From the Latin Crassi-, meaning thick, in reference to the thick ascomatal wall.

Sexual morph: Ascomata scattered, immersed, depressed globose to globose, ostiolate. Ascomatal wall composed of rectangular to polygonal, pale brown to brown cells. Hamathecium numerous, cellular, septate. Asci fissitunicate, cylindrical to clavate, pedicellate, 4-8-spored. Ascospores broadly fusiform, straight, thick-walled, with a submedian septate, 1-3-septate, hyaline, smooth-walled. Asexual morph: Conidiomata pycnidial, scattered, immersed, globose to subglobose, ostiolate. Conidiomatal wall composed of angular, pale brown to brown cells. Conidiophores absent. Conidiogenous cells annellidic, doliiform to ampulliform. Conidia cylindrical, truncate at the base, multi-septate, hyaline, smooth, without sheath.

Type species - Crassiperidium octosporum M. Matsum. \& Kaz. Tanaka

Notes - The new genus Crassiperidium is similar to Asteromassaria in Pleomassariaceae. However, the asexual morph of Asteromassaria differs from that of Crassiperidium in having acervular conidiomata and crescentic to falcate, multi-septate, brown conidia (Sivanesan 1984, Wijayawardene et al. 2016). Crassiperidium resembles Pseudoasteromassaria, which has similar sexual and asexual morphs and the same host plant (Ariyawansa et al. 2015). However, Pseudoasteromassaria is a member of Latoruaceae and is distinguished from Crassiperidium in having pigmented ascospores and phialidic conidiogenesis (Ariyawansa et al. 2015).

Crassiperidium octosporum M. Matsum. \& Kaz. Tanaka, sp. nov.

Fig. 3

Index Fungorum number: IF555727; Facesoffungi number: FoF05593

Etymology - Referring to the asci with 8 spores.

Sexual morph: Ascomata scattered, immersed, depressed globose, 300-500 $\mu \mathrm{m}$ high, $750-1200 \mu \mathrm{m}$ diam., with a central ostiole. Ascomatal wall 7.5-12.5 $\mu \mathrm{m}$ thick at the base, 130-160 $\mu \mathrm{m}$ thick at sides, composed of rectangular to polygonal, 6-14 × 3-9 $\mu \mathrm{m}$ cells. Hamathecium comprising numerous, 1-2 $\mu \mathrm{m}$ wide, hyaline, septate, branched, cellular, pseudoparaphyses. Asci 157.5-202.5 $\times 26-35 \mu \mathrm{m}(\bar{x}=178.7 \times 29.9 \mu \mathrm{m}, \mathrm{n}=13), 8$-spored, fissitunicate, cylindric to clavate, pedicellate (29-49.5 $\mu \mathrm{m}$ long), apically rounded. Ascospores $31-44 \times 12-17 \mu \mathrm{m}(\bar{x}=37.7 \times 14.1 \mu \mathrm{m}, \mathrm{n}=85)$, 1/w 2.1-3.6 $(\bar{x}=2.7, \mathrm{n}=85)$, uni- to bi-seriate, hyaline, broadly fusiform, mostly straight, thickwalled, 1-3-septate, with a submedian primary septum $(0.50-0.56, \bar{x}=0.53, \mathrm{n}=76)$, smoothwalled, with an entire sheath. Asexual morph (nature): Conidiomata pycnidial, scattered, immersed to superficial, depressed globose, 430-550 $\mu \mathrm{m}$ high, 680-790 $\mu \mathrm{m}$ diam., ostiolate. Conidiomatal wall 15-28 $\mu \mathrm{m}$ thick at the base, 30-53 $\mu \mathrm{m}$ thick at sides, composed of rectangular to polygonal, $6-$ $15 \times 3-7.5 \mu \mathrm{m}$, pale brown cells. Conidia 53.5-65 × 10-13 $\mu \mathrm{m}(\bar{x}=59.2 \times 11.7 \mu \mathrm{m}, \mathrm{n}=30), 1 / \mathrm{w}$ 4.4-6.1 $(\bar{x}=5.1, \mathrm{n}=30)$, cylindrical, truncate at the base, 7-septate, hyaline, smooth-walled, without a sheath. Asexual morph (culture): Conidiomata pycnidial, scattered, immersed to superficial, globose, 490-620 $\mu \mathrm{m}$ high, $420-450 \mu \mathrm{m}$ diam., ostiolate. Conidiomatal wall 60-77.5 $\mu \mathrm{m}$ thick at the base, 22.5-70 $\mu \mathrm{m}$ thick at sides. Conidiophores absent. Conidiogenous cells $7.5-$ $11.5 \times 4-5 \mu \mathrm{m}$, annellidic, doliiform to ampulliform. Conidia $(41-) 46-70(-74) \times 10-14.5 \mu \mathrm{m}(\bar{x}=$ 
$57.5 \times 11.6 \mu \mathrm{m}, \mathrm{n}=109), 1 / \mathrm{w} 3.2-6.6(\bar{x}=4.8, \mathrm{n}=109)$, cylindrical, truncate at the base, 7-septate, hyaline, smooth-walled, without a sheath.

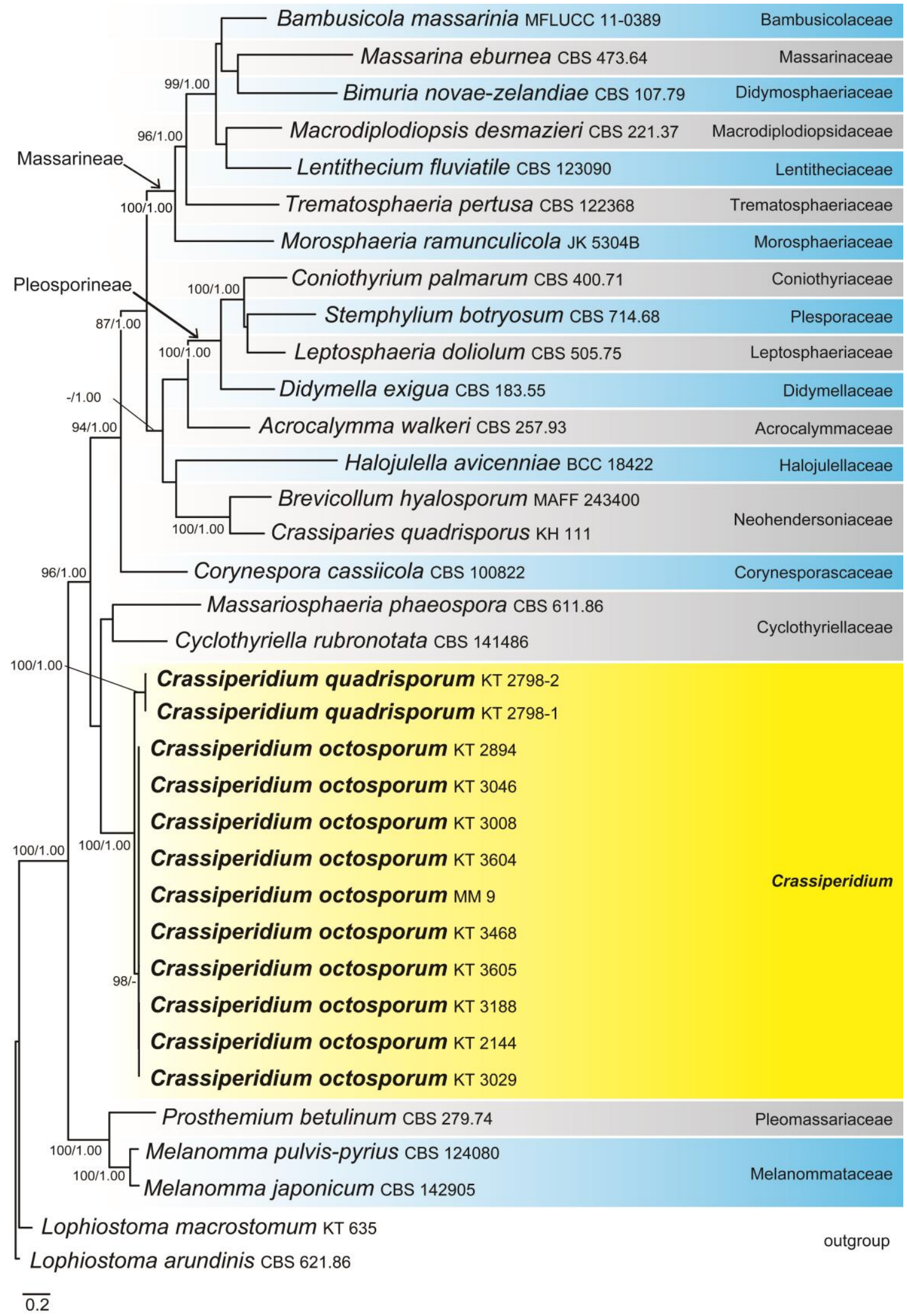

Figure 1 - Maximum-likelihood tree based on combined SSU, LSU and RPB2 sequence. Bootstrap support values and Bayesian posterior probabilities greater than $75 \%$ and 0.95 are given above each node. The tree is rooted to Lophiostoma spp. New species are shown in bold. The scale bar represents nucleotide substitutions per site. 


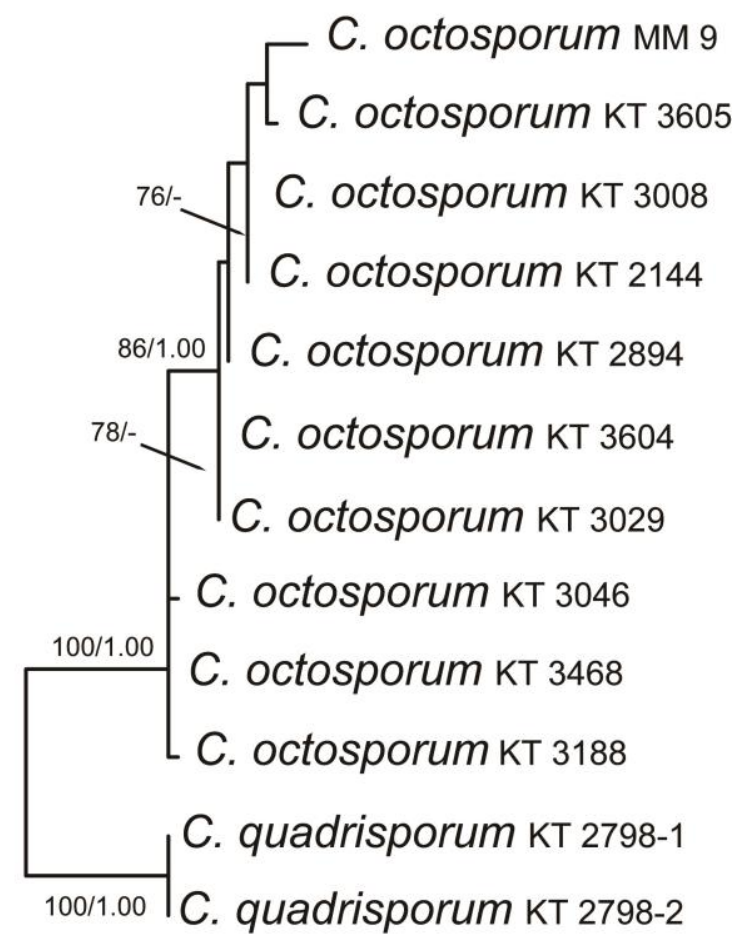

C. octosporum KT 3046

C. octosporum KT 3008

$100 / 1.00$

C. octosporum KT 3604

C. octosporum KT 2894

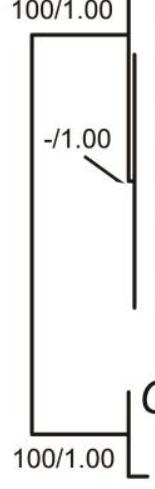

C. octosporum KT 3029

C. octosporum KT 3188

C. octosporum KT 2144

C. octosporum KT 3468

C. quadrisporum KT 2798-1

C. quadrisporum KT 2798-2 $0 . \overline{005}$

\section{RPB2}

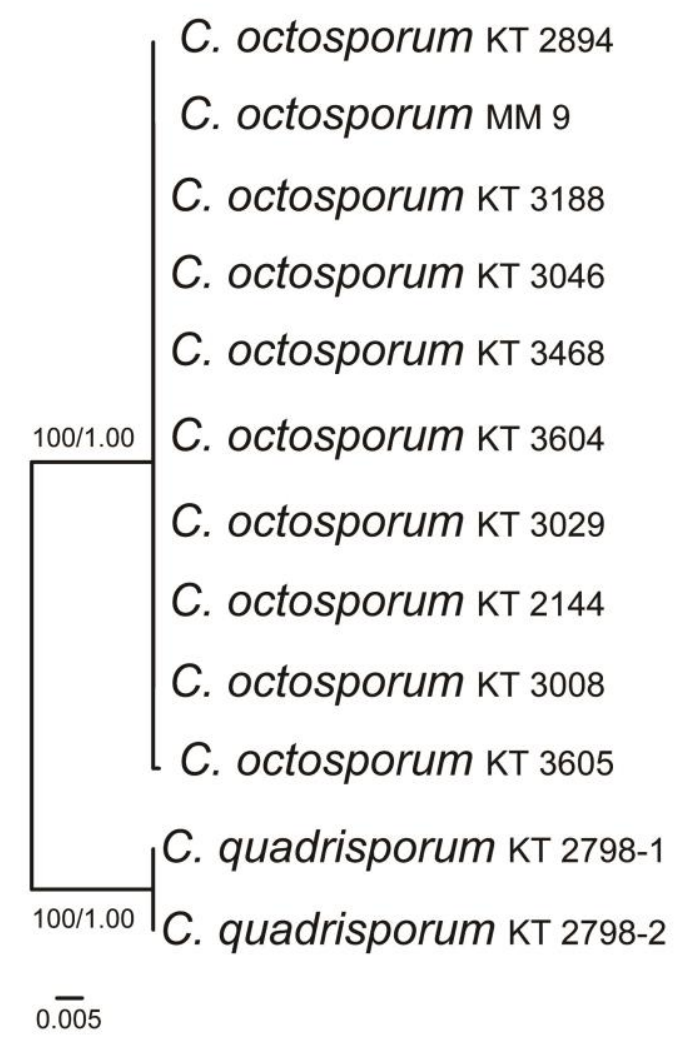

Combine

$\overline{0.006}$

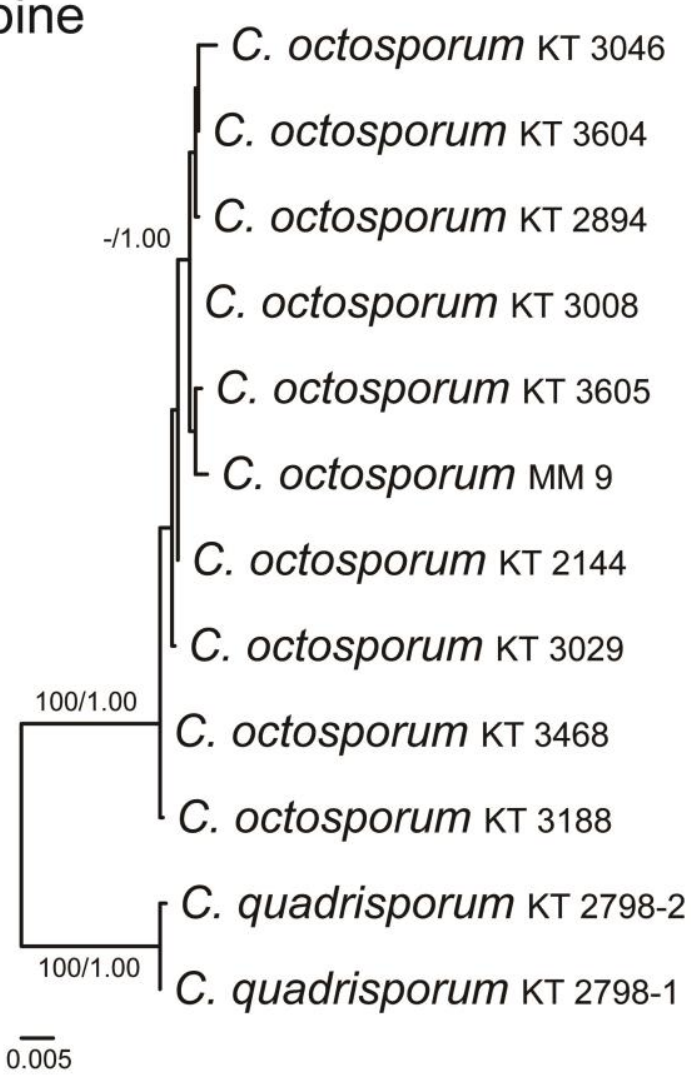

Figure 2 - Maximum-likelihood tree of Crassiperidium species based on each ITS (upper left), TEF1 (upper right) and RPB2 (bottom left), and combined sequences (ITS-TEF1-RPB2; bottom right). Bootstrap support values and Bayesian posterior probabilities greater than $75 \%$ and 0.95 are given above each node. The scale bar represents nucleotide substitutions per site. 


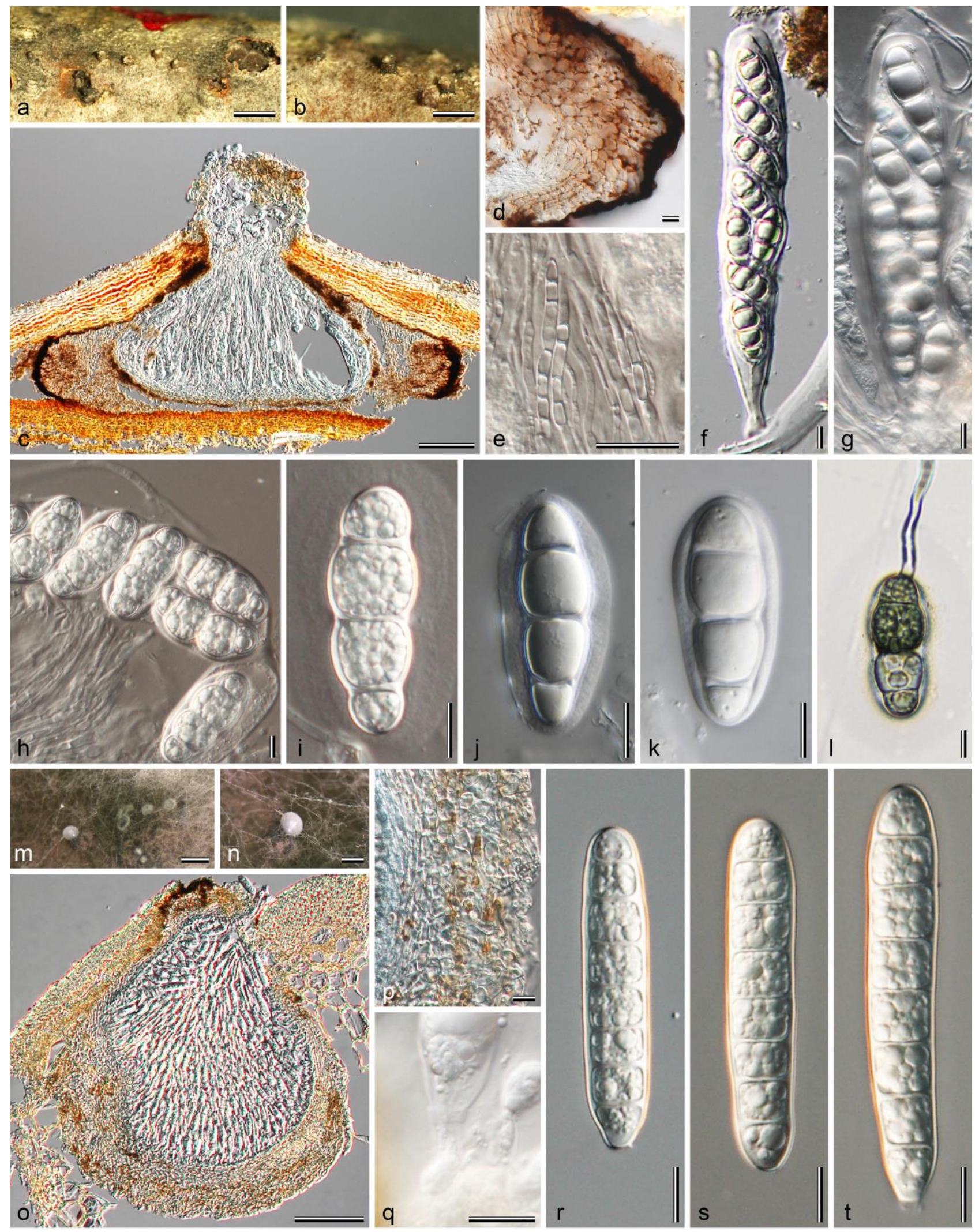

Figure 3 - Crassiperidium octosporum (a-d, f, g, j, k HHUF 30080. e, h, i, 1 HHUF 30603. m, n MAFF 246407. o, p MAFF 246402. q MAFF 246406. r-t MAFF 246404). a, b Ascomata on host surface. c Ascoma in longitudinal section. d Ascomatal wall. e Pseudoparaphyses. f, g Asci. $\mathrm{h}-\mathrm{k}$ Ascospores. 1 Germinating ascospore. $\mathrm{m}$, $\mathrm{n}$ Conidiomata formed in culture. o Conidioma in longitudinal section. $\mathrm{p}$ Conidiomatal wall. $\mathrm{q}$ Conidiogenous cells. $\mathrm{r}-\mathrm{t}$ Conidia. Scar bars: $\mathrm{a}, \mathrm{m}=1$ $\mathrm{mm}, \mathrm{b}, \mathrm{n}=500 \mu \mathrm{m}, \mathrm{c}, \mathrm{o}=100 \mu \mathrm{m}, \mathrm{d}-\mathrm{l}, \mathrm{p}-\mathrm{t}=10 \mu \mathrm{m}$. 
Culture characteristics - Colonies on PDA $20-30 \mathrm{~mm}$ diam. after 2 weeks at $20^{\circ} \mathrm{C}$ in the dark, floccose, White to Greyish Sepia (106, Rayner 1970); reverse White and Greyish Sepia (106) to Grey Olivaceous (107).

Material examined (all on twigs of Fagus crenata) - JAPAN, Iwate, Hanamaki, near Mt. Hayachine, 12 August 2006, K. Tanaka, S. Hatakeyama, Y. Suzuki and H. Yonezawa (HHUF 30080, holotype designated here), ex-holotype culture (ex-ascospore) KT $2144=$ JCM $17827=$ MAFF 242971; Aomori, Nishimeya, The Shirakami Natural Science Park (Hirosaki University), 17 September 2011, K. Tanaka, A. Hashimoto and Y. Sasaki (HHUF 30597), culture (ex-conidium) KT 2894 = MAFF 246399; Aomori, Nishitsugaru, Ajigasawa, mini Shirakami, 4 June 2012, K. Tanaka and T. Shirouzu (HHUF 30598), culture (ex-conidium) KT 3008 = MAFF 246400; Akita, Kazuno, Hachimantai, Mt. Yakeyama, Mousen pass, 24 June 2012, K. Tanaka (HHUF 30599), culture (ex-conidium) KT 3029 = MAFF 246401; Hokkaido, Furano, Yamabe, The University of Tokyo Hokkaido Forest, 18 June 2012, Y.S. Takahashi (HHUF 30600), culture (ex-conidium) KT 3046 = MAFF 246402; Aomori, Hakkoda, Jougakura, 4 November 2012, K. Tanaka (HHUF 30601), culture (ex-conidium) KT 3188 = MAFF 246403; Akita, Hachimantai, Kamazawa, Gosyogake hot spring trail, 22 June 2014, K. Tanaka (HHUF 30602), culture (ex-conidium) KT 3468 = MAFF 246404; Nagano, Shiga Heights, near Hasuike, 22 September 2015, K. Tanaka (HHUF 30603), culture (ex-ascospore) KT 3604 = MAFF 246405; ibid. (HHUF 30604), culture (ex-conidium) KT 3605 = MAFF 246406; Aomori, Hirosaki, Bunkyo-cho, Hirosaki University, 27 August 2013, M. Matsumura (HHUF 30605), culture (ex-conidium) MM 9 = MAFF 246407.

Notes - Crassiperidium octosporum is similar to C. quadrisporum, but differs from the latter in having asci with 8 spores and larger conidia $(57.5 \times 11.6 \mu \mathrm{m}$ vs. $48.6 \times 10.1 \mu \mathrm{m}$ in culture). Furthermore, the sequences of these two species are different at 19, 25, and 33 positions in ITS, TEF1, and RPB2, respectively.

Crassiperidium quadrisporum M. Matsum. \& Kaz. Tanaka, sp. nov.

Fig. 4

Index Fungorum number: IF555728; Facesoffungi number: FoF05594

Etymology - Referring to the asci with 4 spores.

Sexual morph: Ascomata scattered, immersed, depressed globose to globose, $410-500 \mu \mathrm{m}$ high, 720-810 $\mu \mathrm{m}$ diam., with a central ostiole. Ascomatal wall 15-35 $\mu \mathrm{m}$ thick at the base, 100$162 \mu \mathrm{m}$ thick at sides, composed of rectangular to polygonal, 8-20 $\times 5-13 \mu \mathrm{m}$ cells. Hamathecium comprising numerous, 1-2 $\mu \mathrm{m}$ wide, hyaline, septate, branched, cellular, pseudoparaphyses. Asci 145-216 $\times 20-37.5 \mu \mathrm{m}(\bar{x}=180.8 \times 26.3 \mu \mathrm{m}, \mathrm{n}=20), 4$-spored, fissitunicate, cylindric to clavate, pedicellate $(25-55 \mu \mathrm{m}$ long), apically rounded. Ascospores $30-41 \times 11-15.5 \mu \mathrm{m}(\bar{x}=33.8 \times 13.2$ $\mu \mathrm{m}, \mathrm{n}=50), 1 / \mathrm{w} 2.1-3.0(\bar{x}=2.6, \mathrm{n}=50)$, uniseriate, hyaline, broadly fusiform, mostly straight, thick-walled, 1-3-septate, with a submedian primary septum $(0.51-0.56, \bar{x}=0.53, \mathrm{n}=42)$, smoothwalled, with an entire sheath. Asexual morph (culture): Conidiomata pycnidial, scattered, immersed, globose, 320-400 $\mu \mathrm{m}$ high, 280-360 $\mu \mathrm{m}$ diam., ostiolate. Conidiomatal wall 20-62.5 $\mu \mathrm{m}$ thick, composed of rectangular to polygonal, 5-23 $\times 2-7 \mu \mathrm{m}$, pale brown to brown cells. Conidiophores absent. Conidiogenous cells 8-15 $\times 4-8 \mu \mathrm{m}$, annellidic, doliiform to ampulliform. Conidia 38-57 × 8-12 $\mu \mathrm{m}(\bar{x}=48.6 \times 10.1 \mu \mathrm{m}, \mathrm{n}=60), 1 / \mathrm{w} 4.0-5.9(\bar{x}=4.8, \mathrm{n}=60)$, cylindrical, truncate at the base, 7 -septate, hyaline, smooth-walled, without a sheath.

Culture characteristics - Colonies on PDA $25-35 \mathrm{~mm}$ diam. after 2 weeks at $20^{\circ} \mathrm{C}$ in the dark, floccose, White; reverse White and Fuscous Black (104) or Black.

Material examined - JAPAN, Aomori, Nishimeya, The Shirakami Natural Science Park (Hirosaki University), on twigs of Fagus crenata, 2 July 2011, K. Tanaka, A. Hashimoto and Y. Sasaki (HHUF 30596, holotype designated here), ex-holotype cultures (ex-ascospore) KT 2798-1 = JCM 32442 = MAFF 246397, KT 2798-2 = MAFF 246398.

Notes - This species is easily distinguished from C. octosporum by its 4-spored asci. Generally, the number of ascospores per ascus is considered as a useful character for species characterization in Pleosporales (Voglmayr \& Jaklitsch 2011, Hirayama et al. 2014). 


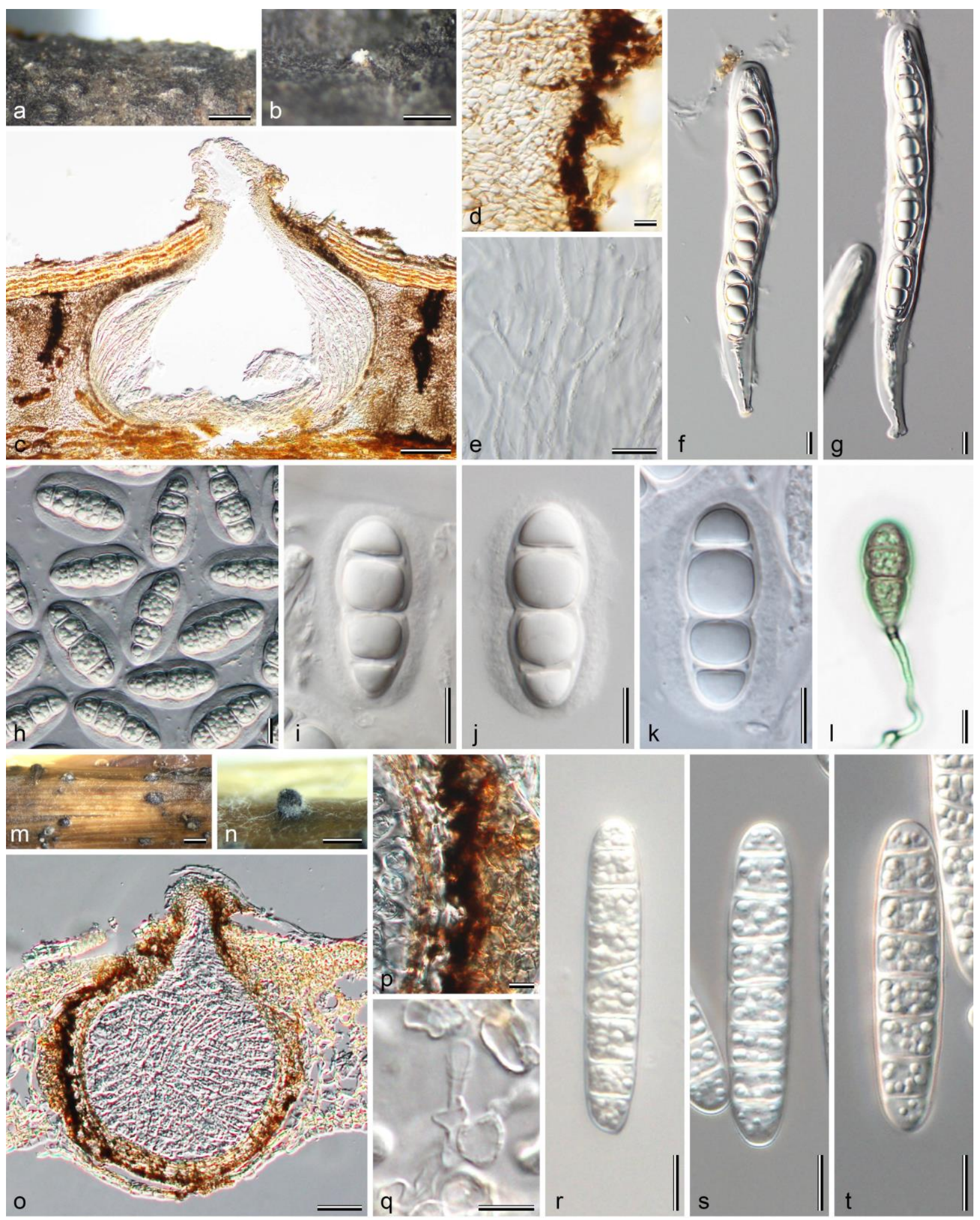

Figure 4 - Crassiperidium quadrisporum (a-1 HHUF 30596. m-t MAFF 246397). a, b Ascomata on host surface. c Ascoma in longitudinal section. d Ascomatal wall. e Pseudoparaphyses. f, g Asci. $\mathrm{h}-\mathrm{k}$ Ascospores. 1 Germinating ascospore. $\mathrm{m}$, $\mathrm{n}$ Conidiomata formed in culture. o Conidioma in longitudinal section. $\mathrm{p}$ Conidiomatal wall. $\mathrm{q}$ Conidiogenous cell. $\mathrm{r}-\mathrm{t}$ Conidia. Scar bars: $\mathrm{a}, \mathrm{m}=1$ $\mathrm{mm}, \mathrm{b}, \mathrm{n}=500 \mu \mathrm{m}, \mathrm{c}, \mathrm{o}=100 \mu \mathrm{m}, \mathrm{d}-\mathrm{l}, \mathrm{p}-\mathrm{t}=10 \mu \mathrm{m}$.

\section{Discussion}

Pleosporales is the largest order in Dothideomycetes. Monographic revision of this order based on the type specimens along with phylogenetic analyses has been published by Zhang et al. 
(2012). Following this publication, many comprehensive works on Pleosporales have been published (e.g., Jaklitsch et al. 2016, Hashimoto et al. 2017b, 2018, Hyde et al. 2017, Voglmayr \& Jaklitsch 2017, Koukol et al. 2018). Currently, 400 genera in 75 families are known in Pleosporales (Wijayawardene et al. 2018), but Crassiperidium does not match any of the previously known genera in this order.

Morphologically, Crassiperidium is most similar to Pseudoasteromassaria (Ariyawansa et al. 2015 ) in that both have globose to depressed globose ascomata with a well-developed ascomatal wall at the sides, pycnidial conidiomata, cylindrical, multi-septate, hyaline conidia, and the same host plant (Fagus crenata). However, Pseudoasteromassaria has pigmented ascospores and phialidic conidiogenous cells, and phylogenetically belongs to Latoruaceae, which is a member of Massarineae (Tanaka et al. 2015). Crassiperidium resembles Asteromassaria in having broadly fusiform ascospores and Fagus as the host plant, but the latter genus typified by A. macrospora has acervular conidiomata and crescentic to falcate, multi-septate, brown conidia (Sivanesan 1984), and is regarded as belonging to Pleomassariaceae (Hyde et al. 2013). Phylogenetically, Crassiperidium forms a sister clade to Cyclothyriella and Massariosphaeria in Cyclothyriellaceae (Fig. 1), but this genus differs from the latter genera that have pigmented ascospores in their sexual morph and phialidic conidiogenesis in their asexual morph (Jaklitsch \& Voglmayr 2016).

Our study shows that the new genus Crassiperidium, is phylogenetically close to Cyclothyriellaceae from analyses of molecular data based on SSU, LSU, and RPB2 sequences, but their relationship was not supported (Fig. 1). Therefore, placement of Crassiperidium at the family level remains unresolved at this time. This genus should thus be treated as a member of an undescribed new family, but further collections of its related lineages are needed to clarify the familial affiliation of this genus.

\section{Acknowledgements}

We thank S. Hatakeyama, Y. Suzuki, H. Yonezawa and Y. Sasaki for their help with the collection of fungal specimens. This work was supported by funds obtained from the Japan Society for the Promotion of Science (JSPS 26291084, 16K07474).

\section{References}

Akaike H. 1974 - A new look at the statistical model identification. IEEE Transactions on Automatic Control 19, 716-723.

Ariyawansa HA, Hyde KD, Jayasiri SC, Buyck B et al. 2015 - Fungal diversity notes 111-252taxonomic and phylogenetic contributions to fungal taxa. Fungal Diversity 75, 27-274.

Baird RE, Watson CE, Woolfolk S. 2007 - Microfungi from bark of healthy and damaged American beech, Fraser fir, and Eastern hemlock trees during an all taxa biodiversity inventory in forests of the Great Smoky Mountains National Park. Southeastern Naturalist 6, $67-82$.

Hashimoto A, Hirayama K, Takahashi H, Matsumura M et al. 2018 - Resolving the Lophiostoma bipolare complex: Generic delimitations within Lophiostomataceae. Studies in Mycology 90, 161-189.

Hashimoto A, Matsumura M, Hirayama K, Fujimoto R et al. 2017a - Pseudodidymellaceae fam. nov.: Phylogenetic affiliations of mycopappus-like genera in Dothideomycetes. Studies in Mycology 87, 187-206.

Hashimoto A, Matsumura M, Hirayama K, Tanaka K. 2017b - Revision of Lophiotremataceae (Pleosporales, Dothideomycetes): Aquasubmersaceae, Cryptocoryneaceae, and Hermatomycetaceae fam. nov. Persoonia 39, 51-73.

Hashimoto A, Matsumura M, Hirayama K, Yonezawa H et al. 2016 - Taxonomy and phylogeny of Cryptocoryneum (Pleosporales, Dothideomycetes). Mycological Progress 15, 45.

Hirayama K, Hashimoto A, Tanaka K. 2014 - A new species, Lophiostoma versicolor, from Japan (Pleosporales, Dothideomycetes). Mycosphere 5, 411-417. 
Hosoya T, Hosaka K, Nam KO. 2018 - A check list of non-lichenised fungi occurring on Fagus crenata, a tree endemic to Japan. Mycology 9, 29-34.

Hyde KD, Jones EG, Liu JK, Ariyawansa H et al. 2013 - Families of Dothideomycetes. Fungal Diversity 63, 1-313.

Hyde KD, Norphanphoun C, Abreu VP, Bazzicalupo A et al. 2017 - Fungal diversity notes 603708: taxonomic and phylogenetic notes on genera and species. Fungal Diversity 87, 1-235.

Jaklitsch WM, Checa J, Blanco MN, Olariaga I et al. 2018 - A preliminary account of the Cucurbitariaceae. Studies in Mycology 90, 71-118.

Jaklitsch WM, Olariaga I, Voglmayr H. 2016 - Teichospora and the Teichosporaceae. Mycological Progress, 15, 31.

Jaklitsch WM, Voglmayr H. 2016 - Hidden diversity in Thyridaria and a new circumscription of the Thyridariaceae. Studies in Mycology 85, 35-64.

Koukol O, Delgado G, Hofmann TA, Piepenbring M. 2018 - Panama, a hot spot for Hermatomyces (Hermatomycetaceae, Pleosporales) with five new species, and a critical synopsis of the genus. IMA Fungus 9, 107-141.

Liu JK, Hyde KD, Jeewon R, Phillips AJL et al. 2017 - Ranking higher taxa using divergence times: a case study in Dothideomycetes. Fungal Diversity 84, 75-99.

Liu YJ, Whelen S, Hall BD. 1999 - Phylogenetic relationships among ascomycetes: evidence from an RNA polymerse II subunit. Molecular Biology and Evolution 16, 1799-1808.

Miller MA, Schwartz T, Pickett BE, He S et al. 2015 - A RESTful API for access to phylogenetic tools via the CIPRES Science Gateway. Evolutionary Bioinformatics 11, 43-48.

Rambaut A, Suchard MA, Xie W, Drummond AJ. 2014 - Tracer 1.6. Available from: http://beast.bio.ed.ac.uk/Tracer. Accessed: September 2018.

Rayner RW. 1970 - A mycological color chart. Commonwealth Mycological Institute and British Mycological Society, UK.

Rehner SA, Buckley E. 2005 - A Beauveria phylogeny inferred from nuclear ITS and EF1- $\alpha$ sequences: evidence for cryptic diversification and links to Cordyceps teleomorphs. Mycologia 97, 84-98.

Rehner SA, Samuels GJ. 1994 - Taxonomy and phylogeny of Gliocladium analysed from nuclear large subunit ribosomal DNA sequences. Mycological Research 98, 625-634.

Ronquist F, Teslenko M, Mark P van der, Ayres DL et al. 2012 - MrBayes 3.2: Efficient Bayesian phylogenetic inference and model choice across a large model space. Systematic Biology 61, 539-542.

Schwarz G. 1978 - Estimating the dimension of a model. The Annals of Statistics 6, 461-464.

Shoemaker RA. 1984 - Canadian and some extralimital Nodulosphaeria and Entodesmium species. Canadian Journal of Botany 62, 2730-2753.

Sivanesan A. 1984 - The bitunicate ascomycetes and their anamorphs. J. Cramer, Vaduz.

Stamatakis A. 2014 - RAxML version 8: A tool for phylogenetic analysis and post-analysis of large phylogenies. Bioinformatics 30, 1312-1313.

Tamura K, Peterson D, Peterson N, Stecher G et al. 2011 - MEGA5: Molecular evolutionary genetics analysis using maximum likelihood, evolutionary distance, and maximum parsimony methods. Molecular Biology and Evolution 28, 2731-2739.

Tanabe AS. 2011 - Kakusan4 and Aminosan: Two programs for comparing nonpartitioned, proportional and separate models for combined molecular phylogenetic analyses of multilocus sequence data. Molecular Ecology Resources 11, 914-921.

Tanaka K, Harada Y. 2003 - Pleosporales in Japan (1): the genus Lophiostoma. Mycoscience 44, 85-96.

Tanaka K, Hirayama K, Yonezawa H, Sato G et al. 2015 - Revision of the Massarineae (Pleosporales, Dothideomycetes). Studies in Mycology 82, 75-136.

Unterseher M, Schnittler M. 2010 - Species richness analysis and ITS rDNA phylogeny revealed the majority of cultivable foliar endophytes from beech (Fagus sylvatica). Fungal Ecology 3, 366-378. 
Voglmayr H, Jaklitsch WM. 2011 - Molecular data reveal high host specificity in the phylogenetically isolated genus Massaria. Fungal Diversity 46, 133-170.

Voglmayr H, Jaklitsch WM. 2017 - Corynespora, Exosporium and Helminthosporium revisitedNew species and generic reclassification. Studies in Mycology 87, 43-76.

White TJ, Bruns T, Lee S, Taylor JW. 1990 - Amplification and direct sequencing of fungal ribosomal RNA genes for phylogenetics. In: Innis MA, Gelfand DH, Sninsky JJ, White TJ (eds) PCR protocols: a guide to methods and applications. Academic Press, San Diego, California, 315-322.

Wijayawardene NN, Hyde KD, Wanasinghe DN, Papizadeh M et al. 2016 - Taxonomy and phylogeny of dematiaceous coelomycetes. Fungal Diversity 77, 1-316.

Wijayawardene NN, Hyde KD, Lumbsch HT, Liu JK et al. 2018 - Outline of Ascomycota: 2017. Fungal Diversity 88, 167-263.

Zhang Y, Crous PW, Schoch CL, Hyde KD. 2012 - Pleosporales. Fungal Diversity 53, 1-221.

Appendix 1 Sequence accessions in GenBank used for phylogenetic analysis

\begin{tabular}{lllll}
\hline \multirow{2}{*}{ Taxon } & \multirow{2}{*}{ Stain no. } & \multicolumn{3}{c}{ GenBank accession no. } \\
\cline { 3 - 5 } & SBU & LSU & RPB2 \\
\hline Acrocalymma walkeri & CBS 257.93 & FJ795495 & FJ795454 & FJ795471 \\
\hline Bambusicola massarinia & MFLUCC 11-0389 & JX442041 & JX442037 & KP761716 \\
\hline Bimuria novae-zelandiae & CBS 107.79 & AY016338 & AY016356 & DQ470917 \\
\hline Brevicollum hyalosporum & MAFF 243400 & LC271236 & LC271239 & LC271249 \\
\hline Coniothyrium palmarum & CBS 400.71 & DQ678008 & EU754153 & DQ677956 \\
\hline Corynespora cassiicola & CBS 100822 & GU296144 & GU301808 & GU371742 \\
\hline Crassiparies quadrisporus & KH 111 & LC100017 & LC100025 & LC271251 \\
\hline Cyclothyriella rubronotata & CBS 141486 & KX650507 & KX650544 & KX650574 \\
\hline Didymella exigua & CBS 183.55 & EU754056 & EU754155 & GU371764 \\
\hline Halojulella avicenniae & BCC 18422 & GU371831 & GU371823 & GU371787 \\
\hline Lentithecium fluviatile & CBS 123090 & FJ795492 & FJ795450 & FJ795467 \\
\hline Leptosphaeria doliolum & CBS 505.75 & GU296159 & GU301827 & KT389640 \\
\hline Lophiostoma arundinis & CBS 621.86 & DQ782383 & DQ782384 & DQ782386 \\
\hline Lophiostoma macrostomum & KT 635 & AB521731 & AB433273 & JN993484 \\
\hline Macrodiplodiopsis desmazieri & CBS 221.37 & DQ678013 & DQ678065 & DQ677961 \\
\hline Massarina eburnea & CBS 473.64 & GU296170 & GU301840 & GU371732 \\
\hline Massariosphaeria phaeospora & CBS 611.86 & GU296173 & GU301843 & GU371794 \\
\hline Melanomma japonicum & CBS 142905 & LC203293 & LC203339 & LC203395 \\
\hline Melanomma pulvis-pyrius & CBS 124080 & GU456302 & GU456323 & GU456350 \\
\hline Morosphaeria ramunculicola & JK 5304B & GU479760 & GU479794 & GU479831 \\
\hline Prosthemium betulinum & CBS 279.74 & DQ678027 & DQ678078 & DQ677976 \\
\hline Stemphylium botryosum & CBS 714.68 & KC584603 & KC584345 & AF107804 \\
\hline Trematosphaeria pertusa & CBS 122368 & FJ201991 & FJ201990 & GU371801 \\
\hline & & & &
\end{tabular}

